\title{
Effect of Interval Training Method On Improving Physical Conditions
}

\author{
Zarwan $^{1 *}$, H Sefri $^{1}$, Z Ade $^{1}$ \\ ${ }^{I}$ Faculty of Sport Science, Universitas Negeri Padang, Prof. dr.Hamka, Padang, Indonesia \\ "Corresponding author. Email: fikzarwan@gmail.com
}

\begin{abstract}
The issue of this study is that students of the Faculty of Sport Sciences possess poor physical condition. This study aims is to improve the ability of physical conditions through interval training. This quasi-experimental, by giving treatment for 16 meetings, involved 9 students. The data were collected through 50 meters running speed test, sit up test, push up test and bleep test. Data were analyzed using dependent samples $t$ test. The results showed that the interval training method can improve the ability of physical conditions. It was confirmed by obtaining tobserve $=4.21>$ ttable $=1,860$ at $\alpha 0.05 \mathrm{df}=\mathrm{n}-1$. Thus, it can be concluded that interval training method is the suitable way to improve the physical condition.
\end{abstract}

Keywords: Interval training method, physical conditions

\section{INTRODUCTION}

The low physical condition ability possessed by the Faculty of Sports Science students underlies this research because as students of the Faculty of Sports Sciences who have activities that are many on and off campus, they should have good physical condition. If this continues, it is feared that students will experience disruption in carrying out all daily activities. Therefore, it is necessary to take anticipatory steps to be able to improve the ability of students' physical conditions. At this time there are many training methods that can be used to improve physical abilities, one of which is the interval training method. Interval method is one of the training methods that is often used to improve the ability of physical conditions. The main feature of the interval method training is the exercise interspersed with other lighter exercises. The purpose of this study was to determine the effect given by the interval training method on improving physical conditions.

\section{Physical Condition}

Physical conditions according to Jonath et al (1981) are distinguished by the narrow and broad sense, in a narrow sense, physical conditions are conditions that include strength, speed, and endurance. While in the broadest sense includes strength, speed, endurance and flexibility, and coordination. According to Röthig et al (1983) physical condition is an element of sports achievement ability that is determined by the mastery of basic motor skills that include resilience, strength, speed, flexibility and balance. Another opinion expressed by Grosser et al (1981), physical conditions are all that limits achievement which includes strength, speed, solidity and flexibility. From some of the opinions above, it can be understood that physical conditions are all elements related to circumstances and physical abilities which consist of strength, speed, endurance, flexibility and balance. The following are some elements of the physical condition that are the focus of this research:

a. Speed

Speed is the ability to repeat a movement with high intensity. Speed is the ability to resolve a certain distance quickly (Bompa et al, 2009). So speed is the ability to move with high intensity and short time.

\section{b. Endurance}

Helga et al (1986) stated that strength is the ability to move as much as time and also overcome the load through working muscles. Bompa (1999) stated that strength is the ability of nerve muscles to overcome internal and external loads. Hardiansyah (2017) argued that strength is the ability of muscles to hold or accept a burden. From some of these opinions, it can be said that strength is the ability of the muscle to overcome the load.

c. Leg muscle exposive power

Bompa (1983) defined explosive power as a result of strength and speed. Edwarsyah et al (2017) stated that explosive power is the ability to display power quickly. So the explosive power of the leg muscles is the ability of the leg muscles to do or release power quickly.

\section{d. Endurance}

Endurance is the body's ability to carry out many activities for a long duration without experiencing significant fatigue. Hardiansyah (2017) stated that 
endurance is the ability to survive from work exhaustion.

\section{Interval Training Method}

Interval training method is a method that is done with the principle of interval, which is a gap between one load and the next load. According to Prakoso (2017) the interval method is characterized by variations in the length of loading, variations in load intensity, variations in load intervals and forms of rest on loading in order to have a purpose that is directed. Hairy (2003) stated that there are 3 types of interval training, namely as follows: 1) Aerobic interval training is a form of exercise that is done repeatedly with very short breaks between 5-15 seconds, 2) Anaerobic aerobics interval training is an exercise whose intensity between $80-95 \%$, the pulse rate is between $85-100 \%$ of the maximum pulse, the working interval is shorter, while the rest interval is between 60-90 seconds, 3) Anaerobic intensity training interval is exercise that is needed more than when competing, even though the interval works shorter, but the rest interval is up to 12 minutes.

The interval training method in this study starts from moderate intensity to maximum intensity. The interval training method is arranged into several sets where each set trains different muscles. In each set consists of several repetitions between one repitition and another repetition interspersed by lighter exercises so that the muscle will have time to do recovery, therefore it is assumed that the interval training method is an effective method to use with the aim of increasing physical condition ability.

\section{METHOD}

This type of research is quasi-experimental. Sampling technique used purposive sampling, a sample of 9 people. The instruments used to measure physical conditions in this study consisted of tests: push ups, sit ups, 40 meter run, standing broad jumps and bleep test. Data analysis techniques used different test $(\mathrm{t})$.

\section{RESULT AND DISCUSSION}

\section{Result}

Pre Test

From the results of the measurement of the initial data physical conditions of endurance, strength, speed and explosive power of the leg muscles obtained the highest score of 59.46, the lowest score of 35.21. Based on the physical condition data group, the calculated average value was 48.87 , the median value was 49.81 , and the standard deviation was 6.83 . The results of more complete initial measurement can be seen in table 1.
Table 1. Pre Test Frequency Distribution.

\begin{tabular}{|c|c|c|c|}
\hline $\begin{array}{c}\text { Interval } \\
\text { Clas } \\
\mathrm{s}\end{array}$ & $\begin{array}{r}\text { Frequency } \\
\mathrm{Ab} \\
\text { sol } \\
\text { ute }\end{array}$ & $\begin{array}{r}\text { Frequency } \\
\text { Relat } \\
\text { ive } \\
(\%)\end{array}$ & Category \\
\hline$>60.10$ & 0 & 0.00 & Very Good \\
\hline 53.37-60.09 & 1 & 11.11 & Good \\
\hline $46.63-53.36$ & 5 & 55.56 & Average \\
\hline $39.90-46.62$ & 2 & 22.22 & Poor \\
\hline$<39.89$ & 1 & 11.11 & Very Poor \\
\hline Total & 9 & 100 & \\
\hline
\end{tabular}

From table 1 above, it can be seen that there are no students $(0.00 \%)$ who have the physical ability to score $>60.10$ in very good category, and 1 person $(11.11 \%)$ has the ability of physical conditions in the interval of 53.37-60.09 in good category, 5 people $(55.56 \%)$ have physical abilities in the interval of 46.63-53.36 in average category, and 2 people $(22.22 \%)$ have physical abilities in the interval of $39.90-46.62$ in poor category and 1 student $(11.11 \%)$ has the physical ability with score $<39.89$ in very poor category. Frequency distribution of the ability of physical conditions can also be seen in histogram 1 .

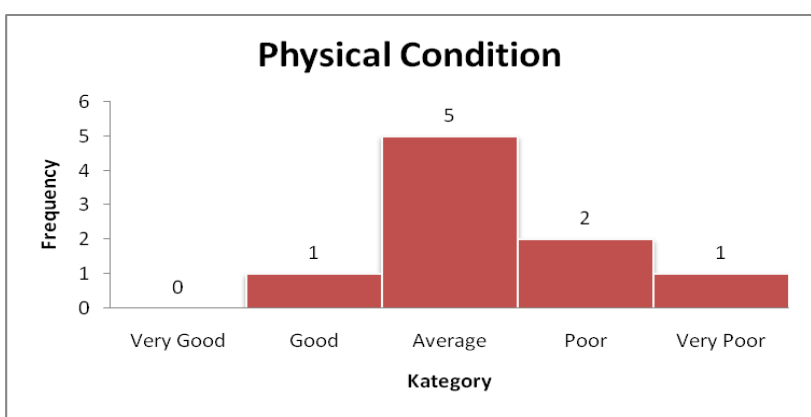

Figure 1. Pre Test Data Histogram Diagram

Post Test

From the results of the measurement of the final data on the physical condition of the sample, the highest score of 64.58 was obtained, the lowest score was 43.20. Based on the physical condition data group, the calculated average value (mean) was 54.85 , the middle value (median) was 55.67, and the standard deviation (standard deviation) was 6.98. For more details the distribution of physical condition data can be seen in table 2 .

Table 2. Post Test Frequency Distribution.

\begin{tabular}{cccc}
\hline $\begin{array}{c}\text { Interval } \\
\text { Class }\end{array}$ & $\begin{array}{c}\text { Frequency } \\
\text { Absolute }\end{array}$ & $\begin{array}{c}\text { Frequency } \\
\text { Relative }(\%)\end{array}$ & Category \\
\hline$>60.10$ & 2 & 22.22 & Very Good \\
$53.37-60.09$ & 4 & 44.44 & Good \\
$46.63-53.36$ & 2 & 22.22 & Average \\
$39.90-46.62$ & 1 & 11.11 & Poor \\
$<39.89$ & 0 & 0.00 & Very Poor \\
Total & 9 & 100 & \\
\hline
\end{tabular}


From table 2, it can be seen that 2 students $(22.22 \%)$ have physical abilities at a score of $>60.10$ in very good category, and 4 people (44.44\%) have physical abilities in interval of 53.37-60.09 in good category, 2 people $(22.22 \%)$ have physical condition abilities in the interval of 46.63-53.36 in average category category, and 1 person $(11.11 \%)$ has the physical ability condition in interval of 39.90-46.62 in poor category and no students $(0.00 \%)$ who have physical ability condition with the score $<39.89$ in very poor category. Frequency distribution of the ability of physical conditions can also be seen in histogram 2.:

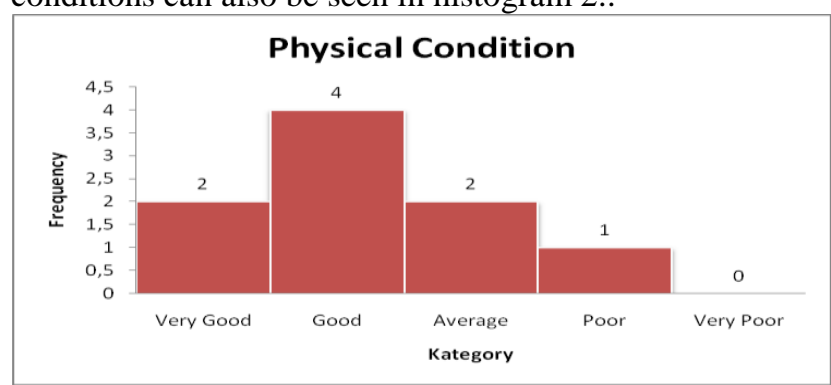

Figure 2. Post Test Data Histogram Diagram.

\section{Requirement Testing Analysis}

Before the data analysis was conducted, the analysis requirements test was carried out, namely the normality test using the Liliefors normality test. Based on the normality test performed, Lobservation is obtained on the pre test data of 0.1645 and the post test data of 0.0991 , while Ltable at $\alpha 0.05$ and $n=9$ of 0.27 , so the $\mathrm{L}_{\text {observation }}<\mathrm{L}$ table can be concluded that the data comes from a normally distributed population. The results of normality testing can be seen in table 3 .

Table 3. Normality Test Result.

\begin{tabular}{cccc}
\hline Group & Lo & Ltable & Information \\
\hline Pre & 0.1535 & 0.27 & Normal \\
Post & 0.1569 & 0.27 & Normal \\
\hline
\end{tabular}

\section{Research Hypothesis Test}

The hypothesis proposed in this study is only one, namely there is a significant influence by the interval training method on increasing physical conditions. $\mathrm{H}_{0}$ test criteria is accepted if tcount <ttable and vice versa $\mathrm{Ha}$ is accepted if tcalc> ttable. Based on the measurements that have been made, the average pre test was 48.87 and the post-test average was 54.85. Data based on data analysis that has been done then obtained tcalc of 4.21 and ttable of $\alpha 0.05$ and $\mathrm{dk} \mathrm{n-1}$ of 1.860 thus the tcalc $4.21>$ ttable $1.860 \mathrm{Ha}$ is accepted in other words the proposed hypothesis is accepted. The calculation results can be seen in table 4 .

Table 4. Hypothesis Testing.

\begin{tabular}{cccccc}
\hline Group & Mean & tcalc & dk & Ttable & Information \\
\hline Pre Test & 48.87 & 4.21 & $\mathrm{n}-1$ & 1.860 & Significant \\
Post Test & 54.85 & & & & \\
\hline
\end{tabular}

\section{Discussion}

Based on the measurement and analysis of the data that has been done, the average initial data obtained was 48.87 and the average final data was 54.85 and from the hypothesis testing performed, it was obtained tcalc of 4.21 , ttable of 1.860 so tcalcis greater than ttable and average the final data is greater than the average, so there is an increase in the ability of significant physical conditions.

The increase in the physical condition using the interval training method was due to the maximum training process carried out by the sample during 16 meetings. Interval method is a series of exercises that are interspersed by periods of time for lighter activities (Hairy, 2003). The implementation of the interval training method is more focused on one muscle which is done by several repetitions or repetitions and interspersed by breaks after which it is continued in the next set by training the other muscles.

In this study, researchers divided interval training exercises into several sets consisting of exercises Set I: endurance training, Set II: arm muscle strength training, Set III: coordination exercises, Set IV: speed training, Set V: explosive power training and Set VI: abdominal muscle training.

Some of the advantages of implementing the interval training method are 1) so that the trainer is more careful in controlling the exercise, 2) easy to observe progress, 3) easy to make corrections and evaluations, so that it will have a significant impact on muscle improvement and general physical condition.

Physical conditions play an important role in the life of every human because if the physical condition is disrupted then there will be a decline in all physical elements themselves such as physical strength, slow running, low resilience, and various other problems, because of this excellent physical condition is needed for sports science faculty students to support all student routines every day. Based on the results of the study, it is necessary to give recommendations to all parties to use the interval training method to improve the ability of physical conditions.

\section{CONCLUSION}

Based on the data analysis that has been done, it can be concluded that the interval training method has a significant influence on improving the physical condition of sports science faculty students.

\section{REFERENCES}

[1] Bompa, Tudor O. 1984. Theory and Methodology of Training. Dubuque, lowa: Kendal/Hunt Publishing Company.

[2] Bompa, Tudor O. 1999. Theory and Methodology of Training. Fourth Edition. USA: Kendal/Hunt Publishing Company. 
[3] Edwarsyah, Hardiansyah Sefri, Syampurma Hilmainur. (2017). Pengaruh Latihan Sirkuit Training Terhadap Kondisi Fisik Atlet Pencak Silat Unit Kegiatan Olahraga Universitas Negeri Padang. Jurnal: Penjakora. Vol. 4 No 1: 51-63.

[4] Grosser, Manfred. Stephan Starischka und Elke Zimmermann. 1981. Krafttraining, Grundlagen, Methoden, Ubungen, Trainingsporagramme. Muenchen: BLV Verlagsgesellschaft mbH.

[5] Hairy, Junusul. 2003. Daya Tahan Aerobik. Jakarta: Direktorat Jendral Olahraga Departemen Pendidikan Nasional

[6] Hardiansyah Sefri. 2017. The Influence Of Circuit Training Method On The Enhancement Of Physical Fitness Of Sports Education Department Students. Proceedings The 1st Yogyakarta international seminar on health, physical education, and sports science: Yogyakarta.

[7] Helga und Manfred Letzelter. 1986. Krafttraining. Theorie-Methoden-Praxis. Hamburg: Rowohlt Taschenbuch Verlag GmbH.

[8] Jonath, Ulrich und Rolf Krempel. 1981. Konditionstraining. Hamburg: Rowohlt Taschenbuch Verlag GmbH.

[9] Prakoso Gregorius Pito Wahyu, FX Sugiyanto. 2017. Pengaruh Metode Latihan dan Dayatahan Otot Tungkai Terhadap Hasil Peningkatan Kapasitas Vo2max Pemain Bola Basket. Jurnal keolahragaan. Vol. 5(2):151-160.

[10] Röthig, Peter 1983. Sportwissenschafliches Lexikon. Schorndorf: Verlag Karl Hofmann. 